\title{
LOAD ANALYSIS OF PROPULSION ENGINE DURING SHIP'S SPEED ACCELERATION
}

\author{
Jan Rosłanowski, Adam Charchalis \\ Gdynia Maritime University \\ Faculty of Marine Engineering \\ Morska Street 83-87, 81-225 Gdynia, Poland \\ tel.: +4858 6901323, +48586901347, fax: +48586901399 \\ e-mail:rosa@am.gdynia.pl,achar@am.gdynia.pl
}

\begin{abstract}
The following paper presents load analysis of propulsion engine during ship's speed acceleration. This process is carried out after manoeuvring in order to receive, as fast as possible, exploitation speeds of the ship, achieved during the voyage. The analysis concerns direct propulsion power system of low-speed engine of constant pitch propeller. Wrong steering process of engine load changes in temporary states, can cause engine overloading, as the result of its operation on the external limiting characteristic and can end up in engine seizure. Control of engine operation is carried on through selecting of adequate setting of rotational speed governor, which for specified external conditions can result in adequate position of fuel link and the choice of adequate fuel index arm dose. Equalization of the power delivered by the engine in given conditions of work with power required by the ship's propeller cooperating with the hull, will establish adequate rotational speed of the engine and finally the speed of the vessel. In order to speed up the sip's motion, there must occur an overflow of propeller thrust over the required thrust (resistance) and this, in turn, is connected with the necessity to ensure the engine power surplus over the power required for a given range of operation or in other words sailing speed. This article presents the working model of ship propelling system during speed acceleration and concerns mainly nonoverload running of the engine. The model described above has been verified during tests in real conditions at sea.
\end{abstract}

Keywords: load propulsion engine, ship's speed acceleration, control engine operation, running non-overload engine

\section{Introduction}

During ship's acceleration, propulsion engine generates additional thrust force, which causes acceleration of the ship motion and additional turning moment to accelerate rotary motion of spinning mass.

An increase of ship s speed can be divided into two stages:

1. An increase of rotation speed of rotating crankshaft mass, propeller with accompanying water, engine and elements connected with it, at almost constant speed of the ship which lasts for a very short period of time,

2. Slow increase of ship s speed, assuming that in this stage, the torque of the engine and of the propeller are equal with each other [1-3].

In power transmission gearless system, ship s speed is a regulated parameter by means of governor setting of propulsion engine rotations. Adjustment of rotational speed is carried out manually by governor setting of rotations automatically by marking on it determined value.

Full load of propulsion engine can be achieved after adequately long time of an increase of governor setting of rotations, which allows to avoid excessive thermal stresses during temperature increase of engine elements.

Pitch increase of rotational speed of an engine during ship s acceleration, takes place in a determined time $\Delta t$. This time is a basic limitation of rotational speed increase to ensure nonoverload work of an engine.

Ship acceleration to an operational speed is carried out gradually through an increase of speed governor setting which determines fuel dose delivered to engine cylinders. 


\section{Overload model for propulsion engine during ship acceleration}

By means of analysis of propulsion engine operation during acceleration of different ships, one can observe the following regularities:

- steering automatically through fixing of determined speed governor setting, rotational moment and rotational speed are ever rising functions and of almost linear character,

- at manual pitch steering of speed governor setting, the course of rotational speed has a character of typical exponential function, representing the answer similar to the answer of second order system, while the torque shows analogical character witch some over regulation $[1,2]$.

Basing on research and the above regularities, one can construct a model similar to a real ship acceleration i.e. an increase of its speed.

Figure 1 presents in coordinates system: thrust-ship s speed, course of propeller thrust during rotational speed increase of propulsion engine resulting in an increase of ship s speed.

Intensity of propulsion engine operation produces the thrust presented by a curve in Fig. 1, which depends on the way of steering.
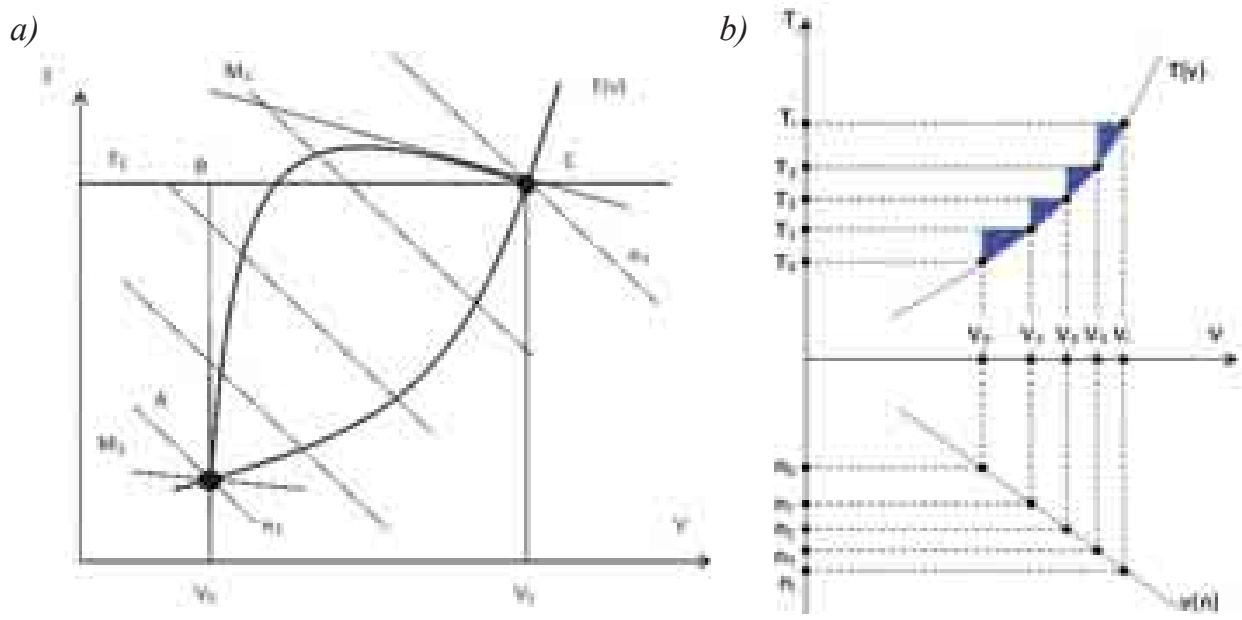

Fig.1. Models of rotational speed increase of the propeller in coordinates system: thrust (T) - ship's speed (v): a) successive increase of ship's speed; b) according to exploitation speed of the ship

When steering violently with few grades of ship acceleration, the curve of the thrust produced earlier by the engine, moves towards increasing values and exceeds the moment required for an increased speed of the ship $\boldsymbol{M}_{\mathbf{1}}$.

Analysis the results of the thrust research, the broken straight line ABC can be replaced (Fig. 1). Such a considerable simplification brings us, most of all, to reality. Other curve approximations $\boldsymbol{T}\left(\boldsymbol{v}, \boldsymbol{M}_{1}\right)$, are possible too eq. instead of section $\mathbf{B C}$ or the curve $\boldsymbol{T}\left(\boldsymbol{v}, \boldsymbol{n}_{1}\right)$ instead of the section $\mathbf{A B}$. In both cases losses of the turning moment for rotating mass acceleration, are not taken into account.

Ship acceleration can be considered as the sum of partial grades of the speed increase. Total time of ship acceleration is calculated after carrying out of thrust linearization: generated by engine operation and needed by the ship s hull, after accepting of the following assumptions:

- defining $\mathrm{z}$ grades of ship acceleration in exploitation range of rotational speed of propulsion engine,

- thrust required by the ship's hull is only a function of its speed and sailing conditions.

- the connection between rotational speed of the propulsion engine and the ship's speed results from conditions of sailing designated by the equation:

$$
T_{T} \cdot \frac{\mathrm{d} \psi}{\mathrm{d} t}-k \cdot \psi=\varphi,
$$


where:

$T_{T}=\frac{m+\lambda}{\left(\frac{n}{v}\right)_{o} \cdot\left(\frac{\partial T_{s}}{\partial n}\right)_{o}}-\begin{aligned} & \text { time-constant of the hull considering rotational speed of the propulsion } \\ & \text { engine, }\end{aligned}$ $k=\frac{\left(\frac{\partial T_{k}}{\partial v}-\frac{\partial T_{s}}{\partial v}\right)_{o}}{\left(\frac{n}{v}\right)_{o} \cdot\left(\frac{\partial T_{s}}{\partial n}\right)_{o}} \begin{aligned} & \text { coefficient of strengthening considering the increase of rotational speed } \\ & \text { of propulsion engine }\end{aligned}$ $\psi=\frac{\Delta v}{v}-$ relative increase of ship's speed, $\varphi=\frac{\Delta n}{n}$ - relative increase of rotational speed of ship propulsion engine.

As the motion of ship s speed increase takes place under the condition:

$$
\frac{\Delta v}{v}=\left(\frac{\Delta v}{v}\right)_{o} \cdot \mathrm{e}^{-\frac{k}{T_{T}} \cdot t} \neq 0
$$

then the integral (1) of the equation will assume the following shape:

$$
\frac{\Delta v}{v}=\left\{\frac{\Delta v}{v} \cdot \frac{1}{k}+\left[\left(\frac{\Delta v}{v}\right)_{o}-\frac{1}{k} \cdot \frac{\Delta n}{n}\right] \cdot e^{-\frac{k}{T_{T}} \cdot t}\right\}
$$

where denotations are as in formula (1).

From the results of research carried out on the ship follows that in definite relative increase of engine rotational speed, one can accept with great precision, linear dependence $\Delta n / n=\gamma \cdot t$ and then following integral is the solution of the equation (1):

$$
\psi=\frac{\Delta v}{v}=\frac{\gamma}{k} \cdot\left[t-\frac{T_{T}}{k}\left(1-\mathrm{e}^{-\frac{k}{T_{T}} \cdot t}\right)\right]
$$

where

$\gamma$ - we find proportionality coefficient of rotational speed increase of propulsion engine.

In this way, the total time of ship acceleration is defined by the formula:

$$
t=(m+\lambda) \sum_{i=1}^{z} \int_{v_{i-1}}^{v_{i}} \frac{d v}{T_{i}-T(v)}
$$

where

$m$ - mass of ship,

$\lambda-$ mass of water accompanying the hull of the ship,

$T_{i} \quad$ - thrust produced by the engine,

$T(v)$ - thrust required by the ship s hull,

$V_{i} \quad$ - ship's speed,

$t \quad$ time.

\section{Consistence evaluation of ship acceleration model with the results of measurements}

To calculate time of ship acceleration, conditions of sailing and the ship's mass have to be considered, the same as during measurement time. There are 10 ranges of propulsion engine steering. From 
rotational speed of 74.5 to $122 \mathrm{rpm}$ and corresponding with these rotations, speeds of the ship from 9.1 knots to 14.7 knots. As steering ranges were accepted such ranges, which began at the moment of rotations, increase until, the motion of the ship was settled with higher rotations and new speed of sailing.

Time of ship acceleration was determined with the help of its model in the same ranges of propulsion engine steering and in the same time.

Measurements were taken during normal operational ship s acceleration and on account of this, they do not fit to the way of propulsion engine steering, presented in the analytical model that is without intervals.

To compare times of ship acceleration, one has chosen such cases, in which there has been the least over steering of propulsion engine before fixing the hull's speed.

The curve of required thrust by the ship s hull, in relation to its motion of given speed in particular ranges of engine steering, was approximated with a straight line. On the basis of measuring results carried out on the ship by means of Jugoslav method, for given operational conditions, propeller thrust characteristic was determined and designated by the formula:

$$
T(v, n)=4.327 n^{2}-12.45 n \cdot v-45.83 v^{2},
$$

where

$T(v, n)$ - thrust generated by propeller in $[\mathrm{kG}]$,

$n \quad-$ rotating speed of propulsion engine in [rpm],

$v \quad-$ speed of the ship in [knots].

Ship's bulk and accompanying water defined by a coefficient $k_{x}=0.03$ for present, at the moment of measuring, operational conditions and is presented by the following formula: $m+\lambda==m\left(1+k_{x}\right)=7.21 \cdot 10^{6}[\mathrm{~kg}]$.

Table 1 presents the results of parameter measurements concerning ship acceleration during normal operating voyage in particular range of engine steering.

Theoretical time of ship s acceleration calculated on the basis of the accepted model and the assumed linear function form of the thrust required by the hull, in given conditions, amounts to:

$$
\left.t\right|_{9.1} ^{14.7}=7.21 \cdot 10^{6} \cdot 5.247 \cdot 10^{-2} \cdot \sum_{i=1}^{10} \int_{v_{i-1}}^{v_{i}} \frac{d v}{T_{i}-\left(a_{i}+b_{i} v\right)}[s]
$$

where

$5.247 \cdot 10^{-2}-$ coefficient resulting from the change of units because in calculation they used $n$ [rpm], $v[\mathrm{knots}], T[\mathrm{kG}], m_{z}[\mathrm{~kg}], g=9.81\left[\mathrm{~m} / \mathrm{s}^{2}\right]$,

$v_{i-1} \quad-$ initial speed of the ship in the range of propulsion engine steering,

$v_{i} \quad-$ final speed of the ship in the range of propulsion engine steering,

$T_{i} \quad-$ required thrust in the final point of steering range,

$T(v)$ - function of the thrust required by the hull, and generated by the propeller, $v_{i}^{*}-v_{i-1}+0.95\left(v_{i}-v_{i-1}\right)-$ upper border of integration.

On the basis of measurements, carried out in respective ranges of propulsion engine steering, during ship's acceleration, dependence of the ship's speed on engine rotations in the present conditions of sailing, has been fixed:

$$
v(n)=0.1519+0.121 \cdot n
$$

where

$n \quad-$ rotational speed of the propulsion engine in [rpm],

$v(n) \quad-$ speed of the ship in [knots].

Taking advantage of functional dependences $v(n)$ and $T(v, n)$ for respective grades of ship's acceleration, values of its speed and thrust generated by the propeller and the time of their increase 
in the range of engine steering, have been calculated. The results of these calculations have been presented in Tab. 2.

Tab. 1. Measured parameters of ship acceleration in particular grades of propulsion engine steering

\begin{tabular}{|c|c|c|c|c|c|}
\hline $\begin{array}{l}\text { number } \\
\text { of range } \\
\text { steering }\end{array}$ & $\begin{array}{l}\text { rotational } \\
\text { speed of } \\
\text { the engine: } \\
\text { a) initial } \\
\text { b) final }\end{array}$ & $\begin{array}{l}\text { speed } \\
\text { of the } \\
\text { ship: } \\
\text { a) initial } \\
\text { b) final }\end{array}$ & $\begin{array}{l}\text { time measured } \\
\text { from the beginning } \\
\text { of measurement } \\
\text { a) initial } \\
\text { b) final }\end{array}$ & $\begin{array}{l}\text { time of acceleration } \\
\text { of the ship from } \\
\text { the initial to } \\
\text { the final parameters } \\
\text { of motion }\end{array}$ & remarks \\
\hline- & {$[\mathrm{rpm}]$} & [knots] & [s] & {$[\mathrm{s}]$} & - \\
\hline 1 & $\begin{array}{l}74.5 \\
80.5\end{array}$ & $\begin{array}{l}9.1 \\
9.9\end{array}$ & $\begin{array}{c}860 \\
1160\end{array}$ & 300 & \multirow{10}{*}{$\begin{array}{l}\text { time of uniform } \\
\text { motion of the ship } \\
\text { has been excluded } \\
\text { from measurements }\end{array}$} \\
\hline 2 & $\begin{array}{l}80.5 \\
84.0 \\
\end{array}$ & $\begin{array}{c}9.9 \\
10.4 \\
\end{array}$ & $\begin{array}{l}1192 \\
1570\end{array}$ & 378 & \\
\hline 3 & $\begin{array}{l}84.0 \\
89.0 \\
\end{array}$ & $\begin{array}{l}10.5 \\
10.8 \\
\end{array}$ & $\begin{array}{l}1586 \\
1734 \\
\end{array}$ & 148 & \\
\hline 4 & $\begin{array}{l}89.0 \\
93.0 \\
\end{array}$ & $\begin{array}{l}10.8 \\
11.2 \\
\end{array}$ & $\begin{array}{l}1734 \\
1816 \\
\end{array}$ & 82 & \\
\hline 5 & $\begin{array}{c}93.0 \\
100.0 \\
\end{array}$ & $\begin{array}{l}11.2 \\
12.4 \\
\end{array}$ & $\begin{array}{l}1816 \\
2090 \\
\end{array}$ & 274 & \\
\hline 6 & $\begin{array}{l}100.0 \\
103.0\end{array}$ & $\begin{array}{l}12.4 \\
12.6\end{array}$ & $\begin{array}{l}2090 \\
2434\end{array}$ & 344 & \\
\hline 7 & $\begin{array}{l}103.0 \\
108.0 \\
\end{array}$ & $\begin{array}{l}12.7 \\
13.2 \\
\end{array}$ & $\begin{array}{l}2440 \\
2808 \\
\end{array}$ & 368 & \\
\hline 8 & $\begin{array}{l}108.0 \\
113.5 \\
\end{array}$ & $\begin{array}{l}13.3 \\
14.0 \\
\end{array}$ & $\begin{array}{l}3040 \\
3590 \\
\end{array}$ & 550 & \\
\hline 9 & $\begin{array}{l}113.5 \\
118.0 \\
\end{array}$ & $\begin{array}{l}14.0 \\
14.4 \\
\end{array}$ & $\begin{array}{l}3620 \\
3970 \\
\end{array}$ & 350 & \\
\hline 10 & $\begin{array}{l}118.0 \\
122.0 \\
\end{array}$ & $\begin{array}{l}14.4 \\
14.7 \\
\end{array}$ & $\begin{array}{l}4140 \\
4390 \\
\end{array}$ & 250 & \\
\hline & \multicolumn{3}{|c|}{ Total time of ship's acceleration } & \multicolumn{2}{|l|}{$\sum_{i=1}^{10}=3044 \mathrm{~s}$} \\
\hline
\end{tabular}

\section{Conclusions}

Comparing calculated parameters of ship's acceleration, on the basis of the accepted and measured parameters, allow formulating the following observations:

1. Proposed analytical model of the propulsion engine loading, defined by the formula (11) is confirmed by the results of measurements carried out during ship s acceleration.

2. Proposed, according to model, time of ship s acceleration to an operative speed, takes place within the bounds of $90-110 \%$ of the measured time which results in a very good operation intensity approximation of piston-connecting rod unit in propulsion engine.

3. Linear regression of thrust curve required by the ship s hull is a good and sufficient of its averaging in respective ranges of propulsion engine steering.

4. An essential factor influencing the time of ship s acceleration is the number of accepted ranges of propulsion engine steering in the whole range of speed increase of the hull.

5. The longer time of ship's acceleration, the lesser surplus of energy generated by the rotational engine in relation to energy required by the hull moving at a given speed.

6. With small number of steering ranges of the propulsion engine, the surplus of energy produced by the engine, increases, and with great number of ranges, decreases. 
7. Linearization of differential equation of ship motion (1) deliverer's parameters of worse value of ship s acceleration and therefore it can be used in case of their minor changes.

Tab. 2. Calculations of ship's acceleration time on the model basis of its course from rotational speed of propulsion engine $75.5 \mathrm{rpm}$ to $122 \mathrm{rpm}$

\begin{tabular}{|c|c|c|c|c|c|c|}
\hline $\begin{array}{l}\text { number } \\
\text { of range } \\
\text { steering }\end{array}$ & $\begin{array}{l}\text { rotational } \\
\text { speed of } \\
\text { the engine } \\
\text { a) initial } \\
\text { b) final } \\
n\end{array}$ & $\begin{array}{l}\text { speed } \\
\text { of the } \\
\text { ship } \\
\text { a) initial } \\
\text { b) final } \\
\boldsymbol{v}(\boldsymbol{n}) \\
\text { according } \\
\text { to formula } \\
\text { (14) }\end{array}$ & $\begin{array}{l}\text { thrust by } \\
\text { propeller } \\
\boldsymbol{T}(\boldsymbol{v}, \boldsymbol{n}) \\
\text { according } \\
\text { to formula } \\
\quad(12)\end{array}$ & $\begin{array}{c}\text { linear regression } \\
\text { of thrust function } \\
\text { required by hull } \\
\boldsymbol{T}(\boldsymbol{v}) \\
\text { in range } \boldsymbol{i} \\
\boldsymbol{T}=\boldsymbol{a}_{\boldsymbol{i}}+\boldsymbol{b}_{\boldsymbol{i}} \boldsymbol{v}\end{array}$ & $\begin{array}{c}\text { upper } \\
\text { border } \\
\text { of } \\
\text { integrati } \\
\text { on } \\
\text { in range } \\
i \\
v_{i}^{*}\end{array}$ & $\begin{array}{c}\text { calculated } \\
\text { time of } \\
\text { ship's } \\
\text { acceleration } \\
\text { in range } \boldsymbol{i} \\
\text { according to } \\
\text { formula (13) } \\
\mathbf{t}\end{array}$ \\
\hline- & [rpm] & [knots] & {$[\mathrm{kG}]$} & {$[\mathrm{kG}]$} & [knots] & {$[\mathrm{s}]$} \\
\hline 1 & $\begin{array}{l}74.5 \\
80.5 \\
\end{array}$ & $\begin{array}{l}9.16 \\
9.89 \\
\end{array}$ & $\begin{array}{l}11674 \\
13645 \\
\end{array}$ & $T=-13067+2699.5 v$ & 9.85 & 391.0 \\
\hline 2 & $\begin{array}{l}80.5 \\
84.0 \\
\end{array}$ & $\begin{array}{c}9.89 \\
10.31 \\
\end{array}$ & $\begin{array}{l}13645 \\
14878 \\
\end{array}$ & $T=-15391+2935.7 v$ & 10.29 & 388.4 \\
\hline 3 & $\begin{array}{l}84.0 \\
89.0\end{array}$ & $\begin{array}{l}10.31 \\
10.92\end{array}$ & $\begin{array}{l}14878 \\
16709\end{array}$ & $T=-16063+3001.4 v$ & 10.89 & 384.1 \\
\hline 4 & $\begin{array}{l}89.0 \\
93.0 \\
\end{array}$ & $\begin{array}{l}10.92 \\
11.40 \\
\end{array}$ & $\begin{array}{l}16709 \\
18269 \\
\end{array}$ & $T=-18784+3250.0 v$ & 11.38 & 364.9 \\
\hline 5 & $\begin{array}{c}93.0 \\
100.0 \\
\end{array}$ & $\begin{array}{l}11.40 \\
12.25 \\
\end{array}$ & $\begin{array}{l}18269 \\
21141 \\
\end{array}$ & $T=-20249+3378.8 v$ & 12.21 & 342.4 \\
\hline 6 & $\begin{array}{l}100.0 \\
103.0 \\
\end{array}$ & \begin{tabular}{|l|}
12.25 \\
12.61 \\
\end{tabular} & $\begin{array}{l}21141 \\
22447 \\
\end{array}$ & $T=-23301+3627.8 v$ & 12.59 & 299.5 \\
\hline 7 & $\begin{array}{l}103.0 \\
108.0 \\
\end{array}$ & \begin{tabular}{|l|}
12.61 \\
13.22 \\
\end{tabular} & $\begin{array}{l}22447 \\
24685 \\
\end{array}$ & $T=-23807+3668.5 v$ & 13.19 & 315.7 \\
\hline 8 & $\begin{array}{l}108.0 \\
113.5 \\
\end{array}$ & $\begin{array}{l}13.22 \\
13.88 \\
\end{array}$ & $\begin{array}{l}24685 \\
27299 \\
\end{array}$ & $T=-27680+3960.6 v$ & 13.85 & 290.9 \\
\hline 9 & $\begin{array}{l}113.5 \\
118.0 \\
\end{array}$ & \begin{tabular}{|l|}
13.88 \\
14.43 \\
\end{tabular} & $\begin{array}{l}27299 \\
29507 \\
\end{array}$ & $T=-28424+4013.6 v$ & 14.40 & 263.9 \\
\hline 10 & $\begin{array}{l}118.0 \\
122.0 \\
\end{array}$ & \begin{tabular}{|l|}
14.43 \\
14.91 \\
\end{tabular} & $\begin{array}{l}29507 \\
31568 \\
\end{array}$ & $T=-32455+4293.8 v$ & 14.89 & 277.6 \\
\hline \multicolumn{7}{|c|}{ Total time of ship s acceleration $\sum_{i=1}^{10}=3318.4 \mathrm{~s}$} \\
\hline
\end{tabular}

\section{References}

[1] Research Works of Marine Power Plant Institute Merchant Marine College in Gdynia: Identification of the mechanical load of the propulsion system during the maneuver the ship to determine the characteristics of the dynamic, Work Task No. 106.5.01.76.

[2] Chachulski, K., Energetic exploitation problems of ship propulsion, Marine Publishing House Gdansk 1991.

[3] Wojnowski, W., Ship Power Plants, Part 1, Naval Academy Publishers, Gdynia 1974. 